Fixed Point Theory, 22(2021), No. 1, 123-140

DOI: $10.24193 /$ fpt-ro.2021.1.09

http://www.math.ubbcluj.ro/ nodeacj/sfptcj.html

\title{
A NOVEL ITERATIVE ALGORITHM WITH CONVERGENCE ANALYSIS FOR SPLIT COMMON FIXED POINTS AND VARIATIONAL INEQUALITY PROBLEMS
}

\author{
MOHAMMAD ESLAMIAN*, YEKINI SHEHU** AND OLANIYI S. IYIOLA*** \\ * Department of Mathematics, University of Science and Technology of Mazandaran, \\ P.O. Box: 48518-78413, Behshahr, Iran \\ E-mail: mhmdeslamian@gmail.com \\ ** Department of Mathematics, Zhejiang Normal University, Jinhua, \\ 321004, People's Republic of China \\ E-mail: yekini.shehu@unn.edu.ng \\ *** Department of Mathematics, Computer Science and Information Systems, \\ California University of Pennsylvania, PA, USA \\ E-mail: iyiola@calu.edu; niyi4oau@gmail.com
}

\begin{abstract}
We propose a new algorithm which can be considered as a combination between the subgradient extragradient method and viscosity methods for solving split common fixed points problem and variational inequality problem. We find a point which belongs to the set of common fixed points of a finite family of demimetric mappings and the common solutions to a system of variational inequalities problem for a family of monotone and Lipschitz continuous operators in a Hilbert space such that its image under a linear transformation belongs to the set of common fixed points of a finite family of demimetric mappings in uniformly convex and smooth Banach space in the image space. The strong convergence of the sequences generated by the algorithm is proved. We also give some numerical results which show that our proposed algorithms are efficient and implementable from the numerical point of view.
\end{abstract}

Key Words and Phrases: Variational inequality, subgradient extragradient method, split common fixed point problems, demimetric mapping.

2020 Mathematics Subject Classification: 47H09, 47H10, 47J20, 47J25.

\section{REFERENCES}

[1] C. Baiocchi, A. Capelo, Variational and Quasivariational Inequalities; Applications to Free Boundary Problems, Wiley, New York, 1984.

[2] H.H. Bauschke, P.L. Combettes, Convex Analysis and Monotone Operator Theory in Hilbert Spaces, Springer, Berlin, 2011.

[3] C. Byrne, A unified treatment of some iterative algorithms in signal processing and image reconstruction, Inverse Problems, 20(2004), 103-120.

[4] C. Byrne, Y. Censor, A. Gibali, S. Reich, The split common null point problem, J. Nonlinear Convex Anal., 13(2012), 759-775.

[5] A. Cegielski, Iterative Methods for Fixed Point Problems in Hilbert Spaces, Lecture Notes in Mathematics, 2057, Springer, Heidelberg, 2012. 
[6] Y. Censor, T. Bortfeld, B. Martin, A. Trofimov, A unified approach for inversion problems in intensity-modulated radiation therapy, Phys. Med. Biol., 51(2006), 2353-2365.

[7] Y. Censor, W. Chen, P.L. Combettes, R. Davidi, G.T. Herman, On the effectiveness of the projection methods for convex feasibility problems with linear inequality constraints, Comput. Optim. Appl., 17(2011), 1-24.

[8] Y. Censor, T. Elfving, A multiprojection algorithms using Bragman projection in a product space, Numer. Algorithms, 8(1994), 221-239.

[9] Y. Censor, A. Gibali, S. Reich, The subgradient extragradient method for solving variational inequalities in Hilbert space, J. Optim. Theory Appl., 148(2011), 318-335.

[10] Y. Censor, A. Gibali, S. Reich, Strong convergence of subgradient extragradient methods for the variational inequality problem in Hilbert space, Optim. Methods Soft., 26(2011), 827-845.

[11] Y. Censor, A. Gibali, S. Reich, Algorithms for the split variational inequality problem, Numerical Algorithms, 59(2012), 301-323.

[12] Y. Censor, A. Segal, The split common fixed point problem for directed operators, J. Convex Anal., 16(2009), 587-600.

[13] M. Eslamian, Split common fixed point and common null point problem, Math. Meth. Appl Sci., 40(2017), 7410-7424.

[14] M. Eslamian, Strong convergence of split equality variational inequality and fixed point problem, Riv. Mat. Univ. Parma, 8(2017), 225-246.

[15] F. Facchinei, J.-S. Pang, Finite-Dimensional Variational Inequalities and Complementarity Problems, Vol. II, Springer Series in Operations Research, Springer, New York, 2003.

[16] S. He, C. Yang, Solving the variational inequality problem defined on intersectoin of finite level sets, Abstr. Appl. Anal., vol. 2013, art. ID 942315, 8 pages.

[17] D. Kinderlehrer, G. Stampacchia, An Introduction to Variational Inequalities and Their Applications, Academic Press, New York, 1980.

[18] I.V. Konnov, Combined Relaxation Methods for Variational Inequalities, Springer, Berlin, 2001.

[19] G.M. Korpelevich, The extragradient method for finding saddle points and other problems, Ekon. Mat. Metody, 12(1976), 747-756.

[20] R. Kraikaew, S. Saejung, Strong convergence of the Halpern subgradient extragradient method for solving variational inequalities in Hilbert spaces, J. Optim. Theory Appl., 163(2014), 399412.

[21] R. Kraikaew, S. Saejung, On split common fixed point problems, J. Math. Anal. Appl., 415(2014), 513-524.

[22] G. Marino, H.K. Xu, Weak and strong convergence theorems for strictly pseudo- contractions in Hilbert spaces, J. Math. Anal. Appl., 329(2007), 336-349.

[23] A. Moudafi, Alternating CQ-algorithm for convex feasibility and split fixed-point problems, J. Nonlinear Convex Anal., 15(2014), 809-818.

[24] Y. Shehu, O.S. Iyiola, Nonlinear iteration method for proximal split feasibility problems, Math. Meth. Appl Sci., 41, 781-802.

[25] W. Takahashi, Introduction to Nonlinear and Convex Analysis, Yokohama Publishers, Yokohama, 2009.

[26] W. Takahashi, The split common fixed point problem and strong convergence theorems by hybrid methods in two Banach spaces, J. Nonlinear Convex Anal., 17(2016), 1051-1067.

[27] W. Takahashi, The split common fixed point problem and the shrinking projection method in Banach spaces, J. Convex Anal., 24(2017), no. 3, 1015-1028.

[28] D.V. Thong, D.V. Hieu, Modified subgradient extragradient algorithms for variational inequality problems and fixed point problems, Optimization, 2017, doi:10.1080/02331934.2017.1377199.

[29] D.V. Thong, D.V. Hieu, Modified subgradient extragradient method for variational inequality problems, Numerical Algorithms, 2017, doi:10.1007/s11075-017-0452-4.

[30] N.T. Vinh, P.T. Hoai, Some subgradient extragradient type algorithms for solving split feasibility and fixed point problems, Math. Method Appl. Sci., 39(2016), 3808-3823.

[31] A.J. Zaslavski, Numerical Optimization with Computational Errors, Springer, 2016.

[32] E. Zeidler, Nonlinear Functional Analysis and Its Applications III: Variational Methods and Optimization, Springer-Verlag, New York, 1985. 
Received: December 19, 2018; Accepted: March 10, 2019. 